\title{
Analysis of Factors Affecting Nurse Performance in DKT Hospital Kediri Hospital
}

\begin{abstract}
Eko Lulus Budiyanto
Magister of Health Study Program of Institut Ilmu Kesehatan

STRADA Indonesia

Email:

ekolulusbudiyanto@gmail.com

Received: October 12, 2019

ABSTRACT

Various complaints from the public regarding the performance of services in hospitals must be cared for by the managers and organizers of hospital services and while the factors that affect performance are satisfaction, compensation and the organization's environment. The general objective of this research is to analyze the influence of factors of satisfaction, compensation and organizational climate on the performance of nurses in the DKT Hospital of Kediri City. The research design used was cross sectional with questionnaire sheet instruments. The population of this study was 90 nurses. Samples were 74 using random sampling techniques, while to determine the effect between variables used ordinal regression test with a significant level of 0.05 . Based on the results of the study, it was found that the organizational climate in the good category was 40 respondents (54.1\%), compensation in the good category was 38 respondents $(51.4 \%)$, had satisfaction in good categories as many as 54 respondents (73\%), and performance in the category good as many as 48 respondents (64.9\%). The results of data analysis showed the factors that most influence performance is the organizational climate with $p$ value 0.003 . Every nurse gets the opportunity to be able to carry out their duties as well as possible so that they have high motivation in working and increasing their productivity. And if the organization's organizational climate is able to build team spirit like this, then by itself it will support the creation of a conducive climate to support nurses performance.
\end{abstract}

Accepted : February 13, 2020

Published : May 10, 2020

Keywords: Satisfaction, compensation, organizational status, performance, nurse

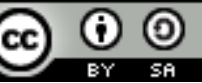

This is an open-acces article distributed under the terms of the Creative Commons Attribution-ShareAlike 4.0 International License. 


\section{INTRODUCTION}

Hospitals are health care facilities that carry out public health efforts and first-degree individual health efforts by prioritizing promotive and preventive efforts to achieve the highest degree of public health in their working area. Nurses including front line workers in hospitals are very decisive about the quality of health services provided to the community (Permenkes No. 75 of 2014). Nurse's performance is an accumulation of the individual performance of each employee in each field. If the performance of each individual is good then it can be ascertained that the performance of public services will be good (Javed, 2010).

Based on the results of a preliminary study on November 10, 2018 on 12 nurses at Kediri DKT Hospital, from interviews and observations obtained $50 \%$ of nurses said that compensation or benefits obtained for nurses and employees were still not enough for their daily needs. The SOP for nursing services is available, but most (75\%) say they don't have time to go to the family's house because there are many tasks in the hospital, according to nurses there is no scheduled supervision from the coordinator and the honorarium is not appropriate, making them lazy to do nursing care.

Performance (performance) is the issue of the world today. This happens as a consequence of the demands of the community on the need for excellent service or high quality services that are inseparable from the standard, because performance is measured by standards. Nurses are expected to be able to show their professional contributions significantly in improving the quality of nursing, which has an impact on health services in general to the organization they work in, and the final impact leads to the quality of life and welfare of the community. One method in assessing nurse performance is by looking at nursing care standards. Nursing care standards are statements that describe the desired quality related to nursing services to clients

\section{METHODS}

The design used in this study is cross-sectional. The population is ners in DKT Hospital on 90. The sample size is 74 respondents using simple random sampling technique. Independent research variables are satisfaction, compensation, organizational status. Dependent variable is performance. Data were collected using questionnaire, then data were analyzed using ordinal regression test with a significance level of $\mathrm{p}$ value $\leq 0.05$.

\section{RESULTS}

Table 1. Distribution $\mathrm{f}$ rekuensi based on Compensation of Nurse

\begin{tabular}{|c|c|c|}
\hline Compensation of Nurse & $\mathrm{n}$ & $\mathrm{f}(\%)$ \\
\hline High & 24 & 32,4 \\
\hline Medium & 38 & 51,4 \\
\hline Low & 12 & 16,2 \\
\hline Total & 74 & 100 \\
\hline
\end{tabular}

Source: Primary data of research in 2018

Based on table 1 shows that of 74 respondents most of is medium categories of the Compensation of Nurse of 38 respondents $(51,4 \%)$.

Table 2. Distribution $\mathrm{f}$ rekuensi based on organisation status

\begin{tabular}{|c|c|c|}
\hline organisation status & $\mathrm{n}$ & $\mathrm{f}(\%)$ \\
\hline High & 40 & 54,1 \\
\hline Medium & 25 & 33,8 \\
\hline Low & 9 & 12,2 \\
\hline Total & 74 & 100 \\
\hline
\end{tabular}

Source: Primary data of research in 2018

Based on table 2 shows that of 74 respondents most of organisation status is high as many as 40 respondents $(54.1 \%)$. 
Table 3. Frequency distribution based on satisfaction

\begin{tabular}{lccc}
\hline & satisfaction & $\mathrm{n}$ & $\mathrm{f}(\%)$ \\
\hline High & 54 & 73 \\
Medium & 15 & 20,3 \\
Low & 5 & 6,8 \\
\hline \multicolumn{2}{c}{ Total } & 74 & 100 \\
\hline
\end{tabular}

Source: Primary data of research in 2018

Based on table 3 shows that from 74 respondents most of the high category of satisfaction of ners as many as 54 respondents $(73 \%)$.

Table 5. Pseudo R-Square Test Results

Pseudo R-Square

\begin{tabular}{ll}
\hline Cox and Snell &, 160 \\
Nagelkerke &, 193 \\
McFadden &, 099 \\
\hline
\end{tabular}

Statistical test results in this study was obtained Pseudo R-square value at Nagelkerke amounted to 0.193 it means factor of compensation, iklim organisation, and satisfaction influence of the performance of nurse by $19,3 \%$ and the rest influenced by other factors equal to $81 \%$.

Based on backward logistic table shows that from two variables after logistic regression test there is one variable that influence of the performance of nurse in DKT Hospital, that organisation of status in hospital of nurse $(\mathrm{p}=0,030)$. This implies that if the organisation of status in hospotal is high will be make effect performance of nurse.

\section{DISCUSSION}

\section{Satisfaction of nurse in DKT Hospital}

Based on the results of the study showed that out of 74 respondents, most of the respondents had satisfaction in the good category as many as 54 respondents $(73 \%)$, and $15(20.3 \%)$ respondents with Enough satisfaction and 5 (6.8\%) with less satisfaction. Based on the results of the cross tabulation, half of the respondents obtained good satisfaction with good performance, namely 37 respondents $(50 \%)$.

Job satisfaction is a very individual thing, because each individual has a different level of satisfaction in accordance with the values that apply in each individual. The more aspects in the work that are in accordance with the wishes of the individual, the higher the level of satisfaction felt. This is in accordance with the statement of Robbins (2003), job satisfaction is a general attitude towards one's work that shows the difference between the amount of rewards received by workers and the amount they believe they should receive. Feelings about satisfaction and dissatisfaction reflect employee perceptions of two important elements in job satisfaction.

Based on the results of the study also found an acknowledgment that is directly related to job satisfaction, this is indicated by all the results of the work carried out always get recognition and fair rewards in accordance with what they do, the suitability of the work with salary / benefits, There are bonuses for work performance, opportunities to promote or develop careers, there are awards for work performance, benefits are given fairly in accordance with achievements, employers provide motivation for employees in completing their duties, this will affect nurse satisfaction to be good.

\section{Compensation of nurse in DKT Hospital}

Based on the results of the study showed that out of 74 respondents, the majority of respondents argued that nurse compensation in the category was enough, namely as many as 38 respondents (51.4\%), good categories $24(32.4 \%)$ respondents and less categories as much as 12 (16.2\%) Based on the results of the study also obtained from 74 respondents, half the respondents who had good satisfaction with good performance as many as 37 respondents (50\%).

One of the factors that affect performance is compensation. Compensation is a fundamental component in the management of human resources in the form of rewards in the form of salaries or 
wages which are a return on the work done by employees (Martocchio, 2011). Compensation is what employees receive in exchange for their contribution to the organization. Compensation is something that employees take into consideration before choosing to work in public services and the reason for the employee to stay in the public service. Compensation can also be a passion for employees to do their jobs. This is supported by the statement of Mondy (2008) who suggested that the general purpose of providing compensation is to attract, retain, and motivate employees. Goerge and Jones (2002) stated that besides compensation can improve performance on the other hand it can also reduce the performance of an employee in an organization.

Based on the results of the study it can be said that the willingness of employees to devote their abilities, knowledge, skills, energy and time, actually expects a reward from the public service that can satisfy their needs. If the compensation program is felt fair and satisfying for employees. Basically, the purpose of compensation is to encourage employees to improve performance. To achieve this, making a compensation program must pay attention to its principles such as fairness, fairness, cost control, balance, incentives, and agreement must be considered. Comprehensive compensation programs will have a negative impact on the relevant public services such as turnover, organizational motivation and low performance.

\section{Organisasion status in DKT Hospital}

Based on the results of the study showed that out of 74 respondents, the majority of respondents thought the organizational climate was in a good category as many as 40 respondents (54.1\%), enough categories $25(33.8 \%)$, and categories less $9(12.2 \%)$ respondents. And based on the results of cross tabulation of 74 respondents, almost half of the respondents had a good organizational climate with good performance as many as 28 respondents (37.8\%).

According to Susanty (2012) the organizational climate is an environment that is perceived and considered to have interactions with individual characteristics of workers who determine their behavior. According to Sullaida (2010) which states that organizational climate is a pattern of repetitive behavior, attitudes and feelings that characterize organizational life. The organizational climate also has the same meaning as the work climate, namely the members' perceptions of how their organization or sub-system deals with its members and its external environment.

This is in accordance with the results of the study where a good organizational climate is obtained including proven from the indicators achieved in the first place related to organizational climate namely Flexibility conformity Flexibility and comfomity is the condition of the organization to provide flexibility to act for employees and adjust themselves to the tasks assigned. This is related to the rules set by the organization, existing policies and procedures. Acceptance of new ideas is a supporting value in developing a conducive organizational climate to achieve organizational goals. Nurses feel that they have a feeling of being happy and comfortable with the environment because they are given the pleasure to convey ideas and also the flexibility in working and their partners who are conducive to increasing their comfort at work. In addition, the fulfillment of the Resposibility indicator, which relates to the feelings of employees carrying out their organizational tasks, is fulfilled, because they are involved in the ongoing process. Where nurses feel they have responsibility in carrying out their duties in accordance with the responsibilities held by each nurse with the support of motivation from fellow nurses so that they strive to always work as well as possible. And also the fulfillment of Standards Feelings which are related to the condition of the organization where management pays attention to the implementation of the task well, the objectives that have been determined and also obtained Reward, which relates to appreciation and recognition for the good work that nurses do and Clarity which is the feeling of employees that they know what is expected of them with work, roles and organizational goals. But there are some nurses assessing the organizational climate in hospitals is not good, this can be supported by the status and duration of work so they have different perceptions related to organizational climate in the hospital. 


\section{Performance of nurse in DKT Hospital}

Based on the results of the study showed that out of 74 respondents, the majority of respondents had performance in good categories as many as 48 respondents (64.9\%), quite 16 categories $(21.6 \%)$, and also less categories 10 (13.5\%) respondent.

Performance also called work performance is a combination of ability, effort and opportunity that can be assessed from the results of his work (Sulistiyani, 2013).

Based on the results of the study obtained performance in the good category this is characterized by the fulfillment of each performance indicator in the good category. The first work performance factor is obtained by nurses working well, diligently, thoroughly, and also having initiatives so that the work goes well and deft and skilled in doing nursing care actions. As for the indicators of responsibility, most nurses are able to fulfill their duties appropriately and also in terms of documenting nursing care that they do in accordance with the actions that nurses have done. As well as the honesty that can be seen from the aspect of the nurse's attitude in giving nursing care to patients where the nurse introduces herself, is friendly and polite in serving the patient, checking the patient's condition, and is also always ready to provide patient assistance in terms of fulfilling the patient's activities. In addition, there is also good adherence and cooperation between nurses as shown by the obedience in obeying Hospital regulations, observing all the actions that have been taken to the patient and also carrying out all nursing actions in accordance with the operational standards determined by the Hospital, and willing openly accept criticism and suggestions and be kind in accepting input from nurses or other health workers.

\section{Factor satisfaction, compensation, and organizational status to performance of nurse in DKT Hospital}

Based on the results of the study using the Statistical Test Ordinal Regression results obtained $\mathrm{p}$ value $=0.045<(\alpha=0.05)$. show the right model and there is a relationship between independent variables and dependent, there is a relationship between compensation factors, organizational climate and satisfaction with nurse performance

Nursing services are very closely related to the performance of nurses in providing nursing care. Robbins (2010) says performance is the end result of an activity. Nursing performance is the work performance shown by the nurse in implementing nursing care so as to produce good output to the customer (organization, patient and nurse itself) in a certain period of time and the nursing performance assessed is the application of nursing care from assessment, planning, nursing diagnosis , implementation and evaluation, where if all elements of nursing care are carried out in accordance with work standards (SAK / SOP) set within a certain period of time then the performance is said to be good (Anwar, 2013).

Based on the research results obtained from the three factors that affect performance there is one most influential factor is the organizational climate factor influences performance. It is known the Sig (2-tailed) value which has 0.003 smaller than $\alpha=0.05$ which means Ho is rejected and H1 is accepted. And the Compensation Factor has no effect on performance, this is known as the Sig (2-tailed) value which has a number 0.13 greater than $\alpha=0.05$, which means that Ho is accepted and H1 is rejected. And also the Satisfaction Factor has no effect on performance, this is known as the Sig (2-tailed) value which has a number of 0.056 greater than $\alpha=0.05$, which means that Ho is accepted and $\mathrm{H} 1$ is rejected.

According to Nirawan (2008) One of the factors that influence employee performance is the climate of public service organizations. Employees in doing their work are also influenced by the compatibility of the organization's climate in public services, where they work, according to Tagiuri and Litwin. Organizational climate is the quality of the organization's internal environment which is relatively ongoing, experienced by members of the organization, influencing their behavior and can be described in one characteristic or nature of the organization. According to Davis. Keith, and Newtrom (2000), organizations tend to attract and retain people who are in accordance with the climate, so that in a certain level the pattern can last. Achieving public services is not only about good results obtained by public services but also processes that have produced good results. The process is related to employee performance in public services.

This is consistent with the results of the study that a good organizational climate influences good performance because a healthy organizational climate can be a competitive advantage when it is able to support the organization's strategy and is able to accommodate environmental changes quickly and 
precisely. Improving service to the community is inseparable from the activities and readiness of employees in carrying out the tasks of service to the community, therefore it must be supported by a conducive organizational climate. Every nurse gets the opportunity to be able to carry out their duties as well as possible so that they have high motivation in working and increasing their productivity. And organizations are able to build team spirit like this, so by itself it will support the creation of a conducive climate to support nurses' personal performance and organizational performance in general.

\section{CONCLUSION}

Most respondents think compensation is in the good category as many as 38 respondents (51.4\%) in the DKT Hospital. Most respondents think the organizational climate is in a good category as many as 40 respondents $(54.1 \%)$ in the DKT Hospital

Most respondents have satisfaction in the good category, namely as many as 54 respondents (73\%) in the DKT Hospital. Most of the respondents had good performance, which was 48 respondents (64.9\%) in the DKT Hospital. The most influential organizational climate factor is the performance of nurses in the DKT Hospital

\section{REFERENCES}

Hani Handoko, 2010, Manajemen Personalia \& Sumberdaya Manusia, Edisi kedua, BPFE UGM Yogyakarta.

Swansburg, R. C. (2000). Pengantar Kepemimpinan dan Manajemen Keperawatan. Jakarta : EGC

Gibson, James L., Donnelly Jr, James H., Ivancevich, John M., Konopaske, Robert (2012). Organizationa Behavior, Structure, Processes, Fourteenth Edition (International Edition).1221 Avenue of The Americas, New York, NY 10020: McGraw-Hill.

Hasibuan, Malayu S.P., 2011. Manajemen Sumber Daya Manusia. Bumi Aksara, Jakarta.

Ambar Teguh Sulistiyani. 2003. Manajemen dan Sumber Daya Manusia : Konsep Teori dan Pengembangan Dalam Konteks Organisasi Publik. Yogyakarta : Graha Ilmu.

Stephen P. Robbins, 1996.Perilaku Organisasi, Konsep, Kontroversi danAplikasi. Alih Bahasa :

Hadyana Pujaatmaka. Edisi Keenam. Penerbit PT.Bhuana Ilmu Populer, Jakarta.

Anwar Prabu Mangkunegara, 2000, Manajemen Sumber Daya Manusia Perusahaan, Cetakan Ke-2, PT. Remaja Rosda Karya, Bandung.

Jewell \& Siegall. 2008. Psikologi Industri/Organisasi Modern. Edisi 2. (terjemahan Pudjaatmaka). Jakarta: Arcan.

Riggio, R.E. (2005). Introduction to Industrial/Organization Psycology. USA : Scott Foresman \& amp.Co

Robbins SP, dan Judge. 2008. Perilaku Organisasi Buku 2, Jakarta : Salemba Empat

Nasution. (2009). Metode Research (Penelitian Ilmiah). Jakarta: Bumi Aksara.

Wexley, Kenneth, N dan Yukl, Gary, terjemahan Muh Shobaruddin, 2003, Perilaku Organisasi dan Psikologi Personalia, Jakarta : Rineka Cipta

Luthans, Fred. 2005. Organizational Behavior 10th Edition. Alih Bahasa: Vivin Andhika, dkk. Yogyakarta: ANDI. 
A.F. Stoner. 2006. Manajemen Sumber Daya Manusia. Jakarta: Bumi Aksara.

Tagiuri, R. \& Litwin G. 1968. Organizational Climate: Expectations of a Concept. Boston: Harvard University Press.

Wirawan. 2008. Budaya dan Iklim Organisasi. Jakarta. Salemba Empat

Hasibuan, Malayu. 2012. “Manajemen Sumber Daya manusia ”. Jakarta: PT Bumi Aksara.

Sadili Samsudin, 2006. Manajemen Sumber Daya Manusia, Penerbit: CV Pustaka Setia.

Mondy, R. W. (2008). Manajemen Sumber Daya Manusia. Jakarta: Erlangga.

Hasibuan, Malayu S.P, 2003, Manajemen Sumber Daya Manusia, Edisi Revisi, Bumi Aksara, Jakarta.

Nawawi, Hadari. (2001). Manajemen Sumber Daya Manusia untuk Bisnis yang Kompetitif.Cetakan Keempat.Penerbit Gadjah Mada University Press, Yogyakarta.

Husein Umar, 2005. Metode Penelitian. Jakarta : Salemba Empat

Dessler, Gary. 2015. Manajemen Sumber Daya Manusia. Jakarta: Salemba Empat.

Depkes RI, (2010) Pedoman Penyelenggaraan Pelayanan Keperawatan Keluarga. Jakarta : Depkes RI

Sugiyono, (2010) Statistika untuk Penelitian, Bandung: Alfabeta

Sovia, S (2012). Analisis Berbagai Faktor Yang Berhubungan Dengan Kinerja Perawat Dalam Pelaksanaan Kunjungan Rumah Di Kota Pariaman Tahun 2012. Tesis. Padang : FKep Unand

Nursalam. (2011). Manajemen Keperawatan Aplikasi Praktek Keperawatan Profesional. Jakarta : Salemba Medika.

Nur Indrati, (2004). Kinerja petugas perawatan kesehatan masyarakat dalam penanganan penderita Tuberculosis di Kabupaten Tanggamus Provinsi Lampung. Tesis Program Paska Sarjana UI. Depok

Wirawan, 2008. Budaya dan Iklim Organisasi. Jakarta. Salemba Empat

Creswell, J. . (2007). Qualitative Inquiry \& Research Design: Choosing Among Five Approaches, 2nd ed. California : Sage Publication.

Notoatmodjo, S. 2007. Promosi Kesehatan dan Ilmu Perilaku. Jakarta : Rineka Cipta

Notoatmodjo,S.2002, Metodologi Penelitian Kesehatan, Rineka Cipta, Jakarta

Notoatmodjo, S. 2011. Kesehatan Masyarakat. Jakarta: Rineka Cipta

Kreitner, Robert, and Kinicki, Angelo, (2003), Perilaku Organisasi, Dalam: Early Suandy (penterjemah), Jakarta: Salemba Empat.

Mondy, R. Wayne. 2008. Manajemen Sumber Daya Manusia. Jakarta: Penerbit Erlangga 
Kaswara dan Santoso. 2008. Pengantar Teori Pengembangan Sumber Daya Manusia, Cetakan Pertama, Penerbit PT. Rineka Cipta, Jakarta

Handoko, T. Hari. 2000. Manajemen Personalia dan Sumber Daya Manusia. Yogyakarta: BPFE.

George, J. M., G. R. Jones. 2002. Understanding and Managing Organizational Behavior. New Jersey: Prentice Hall.

Anwar Prabu Mangkunegara, 2013. Manajemen Sumber Daya Manusia Perusahaan, Remaja Rosdakarya, Bandung.

Robbins, Stephen P. dan Coulter, Mary. 2010. Manajemen Edisi Kesepuluh. Jakarta: penerbit Erlangga

Mathis, R.L. \& J.H. Jackson. 2006. Human Resource Management: ManajemenSumberDayaManusia. Terjemahan Dian Angelia. Jakarta: Salemba Empat.

Robbins, P. Stephen. (2003). Perilaku Organisasi. Edisi Sembilan, Jilid 2. Edisi Bahasa Indonesia. PT Indeks Kelompok Gramedia, Jakarta

Kreitner, Robert, and Kinicki, Angelo, (2003), Perilaku Organisasi, Dalam: Early Suandy (penterjemah), Jakarta: Salemba Empat.

Mondy, R. Wayne. 2008. Manajemen Sumber Daya Manusia. Jakarta: Penerbit Erlangga

Kaswara dan Santoso. 2008. Pengantar Teori Pengembangan Sumber Daya Manusia, Cetakan Pertama, Penerbit PT. Rineka Cipta, Jakarta

Handoko, T. Hari. 2000. Manajemen Personalia dan Sumber Daya Manusia. Yogyakarta: BPFE.

Margono, 2010. Metodologi Penelitian Pendidikan. Jakarta: Rineka Cipta.

Widayat, 2004. Metode Penelitian Pemasaran. Malang : CV. Cahaya Press.

Kusnanto, 2009. Pengantar Profesi dan Praktik Keperawatan Profesional, EGC, Jakarta.

Undang-undang Republik Indonesia. Nomor 38 Tahun 2014. Tentang. Keperawatan.

Undang Undang Republik Indonesia Nomor. 23 Tahun 1992 Tentang Kesehatan

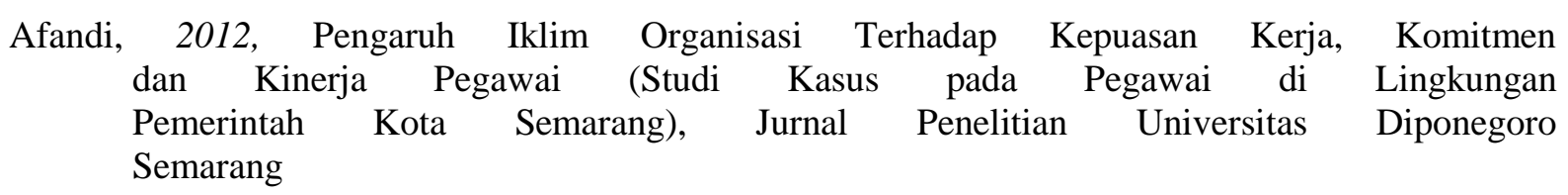

